\title{
On Unnatural Narrative in Post-9/11 Fiction Flight
}

\author{
NI Zeng-xin \\ School of Foreign Languages, \\ Central China Normal University, China
}

\begin{abstract}
In the wake of innumerable and insightful studies on the unnatural narratology at home and abroad, it develops into a post-classical narratology that is comparable to female narratology, rhetoric narratology, and cognitive narratology. Taking the native American writer Sherman Alexie's Flight as its central concern, the essay attends to explore the unnaturalness of the novel and further elaborates on its thematic meaning. In Alexie's Flight, as a post-9/11 fiction, its unnaturalness can be explored by such elements as unnatural storyworlds, unnatural minds and unnatural acts of narration. The intentional violation of conventional narration further highlights the hero's crisis and reconstruction of his identity in the post-9/11 world changed with the miserable memory in his childhood, his sublimation from terrorism to pacifism during his time travel and the regain of love in his final foster family, which consequently contributes to the final change of his appellation from "Zits" to "Michael".
\end{abstract}

Key Words: unnatural narratology, Sherman Alexie, Flight, post-9/11, reconstruction of identity

\section{INTRODUCTION}

With the increasingly heat debates and studies on narratology, a wide variety of narrative theories are brought up mainly from four distinct theoretical perspectives such as rhetorical approach demonstrated by Jim Phelan and Peter Rabinowitz, feminist approach stressed by Robyn Warhol, psychological approach illustrated by David Herman and anti-mimetic approach held by Brian Richardson. Thereinto, Richardson delves into the anti-mimetic approach that violates conventions of realism and conversational storytelling, and claims that "antimimetic narratives refuse to obey or openly flout mimetic conventions; instead of imitating nonfictional discourses, they traduce their conventions"[1], thus calling for the development of unnatural narrative. Western scholars mainly led by Richardson, Jan Alber, Henrik Skov Nielsen, and Stefan Iversen have eagerly explored unnatural narratives and come up with a large number of insightful studies, which have attracted widespread attention in the academic circle.

In effect, not only do the narrative theorists attach significant importance to unnatural narrative, it is also true of many novelists such as Ian Mc Ewan and Michael Shabon in their creations. In some sense, it is fairly uncontroversial to say that narratives are full of unnatural elements. Specifically, according to "Unnatural Narratives, Unnatural Narratology: Beyond Mimetic Models" written by Alber, Iversen, Nielsen, and Richardson cooperatively, "many narratives radically deconstruct the anthropomorphic narrator, the traditional human character, and the minds associated with them, or they may move beyond real-world notions of time and space, thus taking us to the most remote territories of conceptual possibilities"[2]. Additionally, they put forth three unnatural elements: unnatural storyworlds, unnatural minds and unnatural acts of narration, as a frame to analyze the unnatural narratives. Native American writer Sherman Alexie's Flight (2007), as a post-9/11 fiction, describes adventurous and magical experiences of the hero whose mind jumps into other five Americans bodies from 
all walks of life in a row. In light of the unnatural narration that the hero experiences, witnesses and contextualizes violence and terrorism in five different Americans' perspectives, the essay strives to explore the unnaturalness of the novel by first presenting unnatural storyworlds, then discussing unnatural minds and moving on to unnatural acts of narration. To examine unnatural storyworlds, physically impossible worlds can be explored through the example of the cycle temporality in the narration and logically impossible worlds can be examined by the hero Zits's five incarnations. The question of unnatural minds can be next taken up with Zits's mind when he was a foetus and his mental struggle with his incarnations. And impossible narrators and anti-realist characters, namely, the hero's five incarnations in the fiction can serve as examples for illustrating the unnatural acts of narration. Furthermore, by violating the conventions of narrative, the unnaturalness can be explored to present the thematic meaning that the hero's reconstruction of his identity can be realized by his sublimation from terrorism to pacifism, which contributes to the change of his appellation from "Zits" to "Michael".

\section{UNNATURAL STORYWORLDS: FROM TERRORISM TO PACIFISM}

Unlike the classical narratology, which steadfastly advocates the idea that narratives are modeled on the actual world, unnatural narratology emphasizes anti-mimetic and the unnaturalness in narratives. Alber, for instance, restricts the use of the term unnatural to "physically, logically, and humanly impossible scenarios and events (regardless of whether we find them estranging or not)"[3]. And Richardson defines the term unnatural narrative as "one that conspicuously violates conventions of standard narrative forms"[4] and use the term "unnatural" as a synonym for "anti-mimetic". So to speak, the theorists of unnatural narratives have different perspectives and provide alternative or adjacent definitions, which contributes to the bloom of unnatural narratology. In their cooperative essay "Unnatural Narratives, Unnatural Narratology: Beyond Mimetic Models", unnatural storyworlds, which mainly consists of physically impossible storyworld and logically impossible storyworld, appear to be one of the unnatural elements and "closely correlate with the evocation of time and space, i.e., temporal and spatial parameters"[2].

A physically impossible storyworld can create unnatural scenarios that challenge our thinking about such basic narratological concepts as time and space. Just as implied at the very beginning of the novel, Flight simulates the circular narrative structure of Kurt Vonnegut's Slaughterhouse-Five in which Vonnegut "infuses supernatural elements with a compressed view of historical events in order to de-normalize the war experience and expose veins of collective guilt associated with the disseminated images of the American"[5]. Similarly, the storyworlds in Flight are presented in circular time as a whole and Zits's experiences of time travel is interwoven by the backward and forward time. As he spins, shooting in a bank and being shot by a bank guard in the back of the head, he feels he is still alive when he starts to fall but he dies before he hits the floor. During the falling moment, his mind jumps into other men's heads consecutively: "a racist FBI agent attempting to crush a group of Indian activists that resembles the American Indian Movement; an Indian child during the 1876 Battle of Little Big Horn; an elderly soldier of the Seventh Cavalry, perpetrators of the Wounded Knee massacre; an airline pilot named Jimmy who unwittingly trains as a pilot an Ethiopian Muslim, Abbad, who eventually commits some act of terrorism; and his homeless, foul-mouthed father"[6]. Five incarnations in a row occur to Zits the moment he closed his eyes when facing different kinds of violence. As time itself moves backward and forward in time, we are clearly in the realm of the physically impossible. By the same token, when it comes to logically impossible storyworld, Flight describes an illogical story which depicts numerous irreconcilable events. On the one hand, the incarnation itself is an illogical action that violates readers' cognitive convention. On 
the other hand, the five incarnations, some of which happen to be both parties of the same contradiction and conflict, apparently appear to be an antinomic storyworld.

With the construction of a physically and logically impossible storyworld by deconstructing a natural narrative, the hero's change from terrorism to pacifism can be better understood and interpreted by experiencing and contextualizing on different violent events. More specifically, in his first incarnation, Zits thinks that "I felt that bullet crash through my brain. I saw white light. And then it went dark. And I don't mean asleep dark. I mean shot-in-the -brain-untilyou're-dead dark" [7], which describes the process of his first time travel. To be sure, it shows an impossible storyworld in not only physical term but also logical term. When he wakes up for the first time, he finds himself a white handsome young man, an FBI agent. Happening in a reservation, Hank and his partner are attempting to crush a group of Indian activists, which seems like an American Indian movement occurred in 1960s and 1970s. It may be Zits's first time to experience the ethical dilemma as an important FBI agent and a killer. When forced to kill an Indian, Zits-as-Hank falls into a state of narcosis and begins his second incarnation. This time Zits becomes a dumb Indian boy in a gigantic Indian camp, who is the beloved son of "the Arnold Schwarzenegger of Indian warriors"[7] during the 1876 Battle of Little Big Horn. Being the little Indian boy, Zits experiences the happiness in the cozy family with his families' love for him. However, “Zits's 'heaven' of familial warmth is further hallowed by the appearance of its messiah, Crazy Horse"[5]. He remembers, as the boy, the time when white soldiers tortured him and cut his throat. And back as eight-year-old Zits, he recalls the miserable time when he was sexually assaulted by a rich white father. With both memories' juxtaposition, Zits feels his anger building and he feels the needs to revenge while all Indian men, women and children around him want him to revenge. Nevertheless, contemplating the reason of revenging and killing reminds him of the shooting in the bank, he contextualizes the terroristic events. Consequently he comes to an epiphany that "revenge is a circle in a circle in a circle"[7] and gradually steps into a path of peace.

With the witness and contextualization of terrorism during next incarnations, Zits realizes his sublimation from terrorism to pacifism. The moment Zits-as-Indian boy is forced to do violent actions, he closes his eyes and wakes up in old Gus's body for the third incarnation. In the same vein, it happened in the Battle of the Little Bighorn. Nevertheless, what extremely differs from the second incarnation is that Gus serves as the best Indian tracker in the Seventh Cavalry, which is rightly the enemy of Indian camp in the second incarnation. At this time, Zits goes all out to protect a young white soldier "Small Saint" who wants to protect an Indian child "Bow Boy" from a cruel war, "thereby revisiting the ethical revelation"[5]. At the next and penultimate time, Zits wakes up as a white pilot named Jimmy in a airplane. The incarnation exactly mirrors the trauma of 9/11 event which happens in 2001 at its best, representing Americans' severe and far-reaching trauma exerted by terrorism. Zits-as-Jimmy trains as a pilot an Ethiopian Muslim, Abbad, who eventually commits some act of terrorism. The betrayal of friends hurts Jimmy as much as Zits is hurt by his friend Justice who hoaxes Zits into shooting white people in a bank for the reason to revive his mother. He comes to make sense of the fact that everyone betrays others and is betrayed by others for the ground that everyone has various versions virtually. In his final incarnation, Zits becomes a drunk Indian man who distances himself from others by resorting to abusive language and win his respect in an absurd way, such as repeating the sentence "I want some respect"[7]. Zits accidentally sees a photo of five-year-old Zit and his mother. It startles Zits that the man should be his father. Witnessing his father's memory and thoughts when he was born, Zits gets to know that his father was tortured by his grandfather's violence and disdained by repeating "I ain't worth a shit"[7]. Being aware that it is for the fear of being a father that his father abandoned him, Zits gets to realize that peace is of great importance, even at home. 
In a nutshell, as narratives frequently confront us with logically or physically impossible storyworlds, what matters most is to address their potential meanings, instead of steeling clear of them. The unnatural storyworlds of five incarnations delineate his growing experiences psychologically in his time travel. With his mind jumping into different people from all walks of life, Zits obtains broader horizon and gets his mental development. Being more tolerant and eager for peace, he returns his time travel back to the moment before he shoots white people in a bank. Much surprise or no surprise, after witnessing the memory of his father, Zits chooses to forgive, understand, and let guns down. According to Nie, "a person's ethical identity is the result of his ethical selection, which distinguishes him from an animal"[8]. Experiencing, witnessing and contextualizing the terrorism and violence in his incarnations, Zits finally chooses peace.

\section{UNNATURAL MINDS: CRISIS AND RECONSTRUCTION OF IDENTITY}

As unnatural narratology gains growing popularity, unnatural minds appears to play an vital role in exploring the unnaturalness in the analysis of narratives. The term unnatural minds is comprehensively defined by Stefan Iversen that "an unnatural mind is a presented consciousness that in its functions or realizations violates the rules governing the possible world it is part of in a way that resists naturalization or conventionalization"[9]. In "Unnatural Narratives, Unnatural Narratology: Beyond Mimetic Models", Alber coins the term "the unnatural minds of 'omniscient' (or telepathic) first-person narrators (what Genette calls homodiegetic narration with zero focalization)"[10] and points out that "unnatural minds may appear on the level of the story (in the shape of a character), on the level of the narrative discourse (in the case of a heterodiegetic narrator), or both (in the case of a homodiegetic narrator)"[10]. Additionally, according to Shang Biwu, unborn mind presents to be a kind of unnatural minds and these kinds of unnatural minds "violates the physical logicality in real world, transcends the possibility of normal human's attribute"[11]. In Flight, in the same way, the unnatural minds can be illustrated on the level of both story and narrative discourse. Namely, the narrator Zits on the level of narrative discourse, also as a character Zits or Zits-asincarnation on the level of story, shows the unnatural minds consisting in his unnatural memory, unnatural idea and unnatural reason, which account for Zits's crisis and reconstruction of his identity.

In the first place, the narrator Zits, in the first person narrative "I", narrates his unnatural memory about the time when he was a baby, and even before he was born as a foetus. Zits states his unnatural memory at the beginning of the narrative, "my memory is strange that way. I never remember people I've never met and events and places I've never seen"[7]. Born in a single-parent home for his father's departure two minutes after he came into the world, Zits became an orphan when his mother died of a breast cancer at the age of six. Bereft of parents, Zits cherishes his scanty memory about them. He even remembers the scenes happening to his parents before he was born: he remembers his mother and father slowdancing to that Blood, Sweat\& Tears song; he remembers how his father whisper-sang "I Love You More Than You'll Ever Know" to his mother; he remembers how they conceived him that night; he remembers his father took a photo for his mother on an airplane when she was pregnant with him. Zits's subsequent miserable even horrible experiences of being fostered by his aunt and his twenty-one foster families make the unnatural memory more precious. As a consequent, being a half-breed Indian orphan who is not only abandoned by the white American family, but also marginalized by his Indian foster families, Zits loses the sense of belonging and steps into the crisis of identity due to the lack of warmth and love in his childhood. 
In the second place, out of his memory and miss for his parents and with the unnatural idea that ghost dance can revive his mother, Zits is hoaxed by Justice, who seems to be much knowledgeable and experienced and becomes Zits's close friend in prison, into shooting white men in a bank. According to Zits, ghost dance is "this ceremony created by the Paiute holy man Wovoka, back in the eighteen-seventies. He said, if the Indians danced this dance long enough, all the dead Indians would return and the white people would disappear"[7]. It can be wholeheartedly agree that the unnatural idea is harmless said by innocent Zits, but it is utilized by malicious Justice to hoax Zits into practicing it in reality, which turns out to be a terrorism. Zits, being questioned about the "ghost dance" repeatedly by the white pretty boy who "is an anarchist and a terrorist" and "makes Zits full of hatred against the government"[12], finally he is persuaded to shoot white people in a bank at random as a new form of "ghost dance" on the pretext that killing someone will bring his mother back to life. Taking advantages of lack of love in family and showing his care and love to Zits, Justice purposely cheats and induces Zits to shoot and kill white human as a way of purifying the whites' sins committed to black Americans hundreds of years ago. In light of the fact that Justice does not show up as he committed the crime, Zits comes to realize that he is deceived and betrayed by his "best friend". With the unnatural idea, a false conviction, Zits further sinks into the crisis of identity. Meanwhile, the unnatural idea about ghost dance lands Zits a position to experience the time travel when he is shot by a bank guard, which paves the way for the following five incarnations. In the third place, unnatural reason, as an element to explore the unnatural minds, appears during Zits's time travel when his reason struggle with his incarnation. In his third incarnation, Zits's reason struggles mentally with his incarnation Gus's for the first time. It happens in the Battle of the Little Bighorn where Gus serves as the best Indian tracker in the Seventh Cavalry, which is rightly the enemy of Indian camp in the second incarnation. In Gus's body, Zits confessed at fist that he can not control Gus entirely.

"I can't completely control Gus. I can move his arms and legs. I can talk with his voice. And I can think my own thoughts. But Gus is stronger than I am. His memories become my memories, too. This is new. I couldn't see into the past of the other bodies I've inhabited."[7]

Combining Zits's unnatural memory and Gus's together, Zits-as-Gus has the same memory about the harrowing scene that a naked body of a mother with three arrows shooting at her belly, whose right hand forever reaching out for her littler daughter with three arrows on her belly too, who is the only one died with her dress on. Zits feels Gus's huge guilty and rage, which infects him and stimulates his impulse to revenge. As a half-breed Indian who is marginalized by both Indians and white Americans, Zits can not decide which party is righteous or evil during the battle. However, what he can affirm is that he longs for peace instead of violence, which leads to Zits's confrontation with Gus when he sees a touching scene that a young white soldier "Small Saint" who wants to protect an Indian child "Bow Boy" from the cruel war. It follows that Zits's unnatural reason controls and defeats Gus's emotion and saves the white soldier and the little Indian child successfully. The process makes it exciting and inspiring for Zits to combat for his righteous values valorously.

With a close look at the unnatural memory, unnatural minds and unnatural reason, Zits's unnatural minds are elaborated on at length. It is thus worth noting that the unnatural minds, which run through the narrator Zits's whole realistic experiences and magical experiences in the unnatural storyworlds, contributes significantly to Zits's mental development. After experiencing the loss of love in his own family and moral dilemma, obtaining the sense of responsibility and moral obligation during his time travel, Zits finally steps out of the crisis of identity and reconstructs his identity. 


\section{UNNATURAL ACTS OF NARRATION: FROM ZITS TO MICHEAL}

While the vast majority of scholars emphasize and explore the different types of narrators in normal narratives, such as "extradiegetic", "intradiegetic", "hypodiegetic", "hypohypodiegetic"[10] put forth according to narrative levels by Rimmon-Kenan, Alber pays more attention to unnatural narrator in unnatural narratives. In "Unnatural Narratives, Unnatural Narratology: Beyond Mimetic Models", Alber postulates that "many readers and theoreticians have grown used to unnatural acts of narration in fictional third-person narratives, including reflector-mode narratives or narrative 'omniscience"'[2] and points out that "in some firstperson narratives, the narrator knows significantly more than he could if he or she were a real person"[2]. Richardson, moreover, calls attention to the unnatural narratives in which "the same character's thoughts and actions are narrated in different persons, or when entirely disparate narrators converge" [4]. In view of Flight, on the one hand, the narrator Zits employs both "I" and "he" to describe the same character which combines Zits and other incarnations as a whole during his time travel; on the other hand, it is narrated by an "omniscient" first-person narrator, namely, Zits is not only a narrator telling the story of himself, but also a character who knows more than he could in the story.

As should be apparent, in Flight, the first person account of the hero is accompanied by the third person narrative of one of the characters. Zits's incarnation is narrated by different narrators by employing "I" and "he" when it comes that the same character is narrated by different narrators. In the third incarnation as Gus, the narrator Zits begins to employ "he" and "I" to narrate Zits-as-Gus's interior monologue as it is the first time that Zits senses that Gus exists as an independent character, whose power is too strong to control. When seeing at the fierce sight that an innocent girl is dead with three arrow in her belly, "Gus's eyes water at the memory. My eyes water"[7]. Zits-as-Gus owns two different parties' memory at the same event, as a consequence of which Zits can sense sensibly Gus's emotion and further understand the reason behind the war. "This is not my sadness. This all belongs to Gus, and his grief and rage are huge, so my grief and rage are huge, too"[7]. In the same vein, the fourth incarnation of Zits-as-Jimmy is narrated by "he" and "I". "He is having an affair with a woman he doesn't love. So he's cheating on her, too, sort of. I mean, I don't think you're supposed to have sex with people you don't love. I know, I know, I know. People do it all the time. But..."[7], after knowing Jimmy's faithlessness to his wife, Zits narrates his interior monologue by employing the first, second and third person narrative to convey his discontentment with Jimmy, as well as his own father indeed. Zits uses "he" to describe the fact that Jimmy has an affair with Helda whom he does not love. It follows that Zits expresses his own disagreement to Jimmy by employing "I". The second person narrative "you" and three "I know", which seems like a kind of direct conversation with Jimmy, is used to further clarify Zits's critical attitude towards the affairs. For Jimmy's part, after being discovered by his wife about his betrayal to their marriage, Jimmy feels so guilty. "He wants to be punished for his crimes. I want to be punished for my crimes"[7], which shows Zits-as-Jimmy's guilt towards the disloyalty in marriage. The final incarnation turns out to be Zits's father. Zits narrates he struggles with his father mentally and finally succeeds to find out the real reason for his father's leaving: "So I push against my father's mind and soul. I crash through his fortifications and rampage into his memory and tear..."[7]. Zits realizes his father left him and his mother on the grounds of being afraid of being a father for father's own miserable memory of childhood and father. Consequently, Zits begins to understand his father for his irresponsibility.

What in follows, it can be easily noticed that the narrator Zits knows much more in the unnatural narrative than he should as a character. Firstly, the first-person narrator even knows the past before he was born. For example, at the very beginning of the narrative, the narrator Zits with the unnatural mind, shows how his parents fell in love with each other as well as how 
he was conceived. Secondly, the character Zits, as a fifteen-year-old boy, knows how to explore and understand adults' inner thoughts. When arrested by a cop Dave after he escapes from his twentieth foster family, Zits describes cops as the men who "endured chaotic and brutal childhood, so they become cops because they want to create order in the world"[7] and narrates "he's(Dave) never said much about his life, but I can tell he's scarred. And he knows I'm scarred, too"[7]. He understands Dave and even knows what Dave knows. Thirdly, except from narrating what he experiences, the narrator Zits also knows narrates what he never sees and hears. After his time travel, Zits returns to the moment before he shoots around in the bank. He recalls and reflects on his suffering experiences since he was born. Lack of parental love, the pathetic boy was taken care of by his only family Aunt Zooey but then was abandoned again who slapped him every time he told her the fact that he was hurt by her boyfriend on bed in the middle of night. As a child at the age of ten, the phase of growing period that is in extreme need of parents' accompany and love in family, Zits was bereft of all his families. In consequent years, Zits is adopted by and escapes from twenty foster families consecutively. After meeting a kid named Justice who teaches him how to use gun, Zits finally comes to realize that "I am tired of hurting. I am tired of being hurt"[7], hands in his two guns and gets into the jail. Once Dave comes to the cell and says "you are going to die"[7] to Zits with tears, Zits narrates Dave's memory that he never sees. By narrating the story happening to two babies who are scalded and killed by hot boiled water because of their drunk parents in detail, Zits begins to understand Dave's sorrow and regret for his disability to save those children he could have saved. Influenced by the love and kindness of Dave and his family, Zits finally confesses to his foster mother, Dave's wife, that his name is Micheal.

In a word, the employment of "omniscient" first-person narrator accompanied with the third person narrative of other characters, breaks the traditional acts of narration, which further accounts for the awake of Zits's conscience and that Zits's mental development and reconstruction of identity lead to the change of his appellation from Zits to Micheal.

\section{CONCLUSION}

With the increasing popularity of unnatural narratology, the essay attempts to explore the unnaturalness in Flight, which further interprets its variant themes with the link of the unnatural elements. As Shang Biwu asserts, "the unnatural narrative, as an innovative narratology, is not only intended to highlight the fictionality of literature and to challenge the process of reading, but also attends to make certain ideological influences"[11]. To some extent, novelists are inclined to better point out the current biggest social and moral issues by employing unnatural narratives.

As people are awake and alert to violence and terrorism in the post-9/11 world, more attentions must be paid to the root of and resolution to such kind of trauma. Alexie attempts to "links international terrorism committed against the United States to terrorist acts committed by the United States"[13] so as to put terrorism in a historical and objective view. In this way, the hero Zits in Flight may grab different understandings towards terrorism from both sides of the attacker and the victim. In Flight, the hero, nicknaming himself "Zits", appears to be an orphan suffered violence and pain from different people, which leads to his delinquency and inclination to terrorism after his sojourn with Justice in prison. In contrast at the end of the novel, he travels his time back before he shoots white Americans in a bank and come to the epiphany that people ought to live in a peaceful world with more tolerance and less violence. With the application of unnatural narrative, such as unnatural storyworlds, unnatural minds and unnatural acts of narration, Zits's mental development is narrated vividly and thoughtprovokingly. His covert reconstruction of his identity in both family and society and the 
propensity from terrorism to pacifism leads to the overt transformation of his name from Zits to Micheal.

\section{References}

Herman, D., et al., Narrative theory: Core concepts and critical debates2012: The Ohio State University Press.

Alber, J., et al., Unnatural narratives, unnatural narratology: Beyond mimetic models. Narrative, 2010. 18(2): p. 113136.

Alber, J., Unnatural narrative: Impossible worlds in fiction and drama2016: U of Nebraska Press.

Richardson, B. and R. BRIAN, Unnatural voices: Extreme narration in modern and contemporary fiction2006: Ohio State University Press.

Cooper, L.R., Beyond 9/11: Trauma and the Limits of Empathy in Sherman Alexie's Flight. Studies in American Fiction, 2015. 42(1): p. 123-144.

Salaita, S., Concocting Terrorism off the Reservation: Liberal Orientalism in Sherman Alexie's Post-9/11 Fiction. Studies in American Indian Literatures, 2010. 22(2): p. 22-41.

Alexie, S., Flight2007, New York: Open Road Integrated Media.

Zhenzhao, N., Introduction to ethical literary criticism. Beijing: Peking UP, 2014.

Stefan, I., et al., Unnatural Minds. 2013.

Rimmon-Kenan, S., Narrative Fiction: Contemporary Poetics. 2nd ed2005, London and New York: Routledge.

Biwu, S., An Ethical Interpretation of Unnatural Narrative: The Foetus Narrator and Its Brian Text in Ian McEwan's Nutshell. Foreign Literature Studies, 2018(3): p. 4.

Harbin and China, Reflections on Terrorism:Sherman Alexie's Post-9/11 Writing. Contemporary Foreign Literature, 2012.

Coulombe, J.L., The Efficacy of Humor in Sherman Alexie's Flight: Violence, Vulnerability, and the Post-9/11 World. Multi-Ethnic Literature of the United States, 2013. 39(1): p. 130-148. 